\title{
PENGARUH NILAI TUKAR RIIL TERHADAP NERACA PERDAGANGAN BILATERAL INDONESIA: \\ Kondisi Marshall-Lerner dan Fenomena J-curve
}

\author{
Jardine A Husman
}

\begin{abstract}
The paper analyzes the Marshall-Lerner condition on Indonesian trade with its major trading partners. This study also investigates the existance of $J$-curve and covers the issue of the indirect pass-through effect, particularly the impact of the real exchange rate change on the Indonesian export performance.

We apply the VECM model on the quarterly data of Indonesia and 8 of its trading partners, during the period of 1993:1-2004:4. The estimation result on the overall sample shows that the condition of Marshall-Lerner is satisfied, implying the rupiahs depreciation will increase the Indonesian export. Using each trading partner pair data, the Marshall-Lerner condition is not satisfied on the case of Singapore and England due to the inelastic export demand as the Indonesian export to both countries is mostly a consumption goods.

The J-curve phenomenon is only found in the case of Japan, South Korea and Germany implying the depreciation of Rupiahs will increase Indonesian export. The elasticity estimation shows that $1 \%$ depreciation of Rupiahs only raise Indonesian export-import ratio by $0.37 \%$. This small number strongly indicates that real exchange rate only plays a minor role on the Indonesian export performance.
\end{abstract}

JEL Classification: C22, F14

Keywords: Exchange rate, J-Curve, Marshall-Lerner, export, VECM. 


\section{PENDAHULUAN}

Adanya tekanan pada nilai tukar belakangan ini kembali menimbulkan pertanyaan apakah depresiasi secara riil akan berdampak terhadap kinerja ekspor dan selanjutnya neraca perdagangan atau net-ekspor Indonesia. Kebijakan nilai tukar yang akan dirumuskan tentunya selain untuk menjaga kestabilan harga juga dilandasi oleh pertimbangan dampak nilai tukar terhadap kinerja perdagangan internasional Indonesia, yang selanjutnya akan berdampak pada PDB dan inflasi.

Transmisi kebijakan moneter melalui jalur nilai tukar tersebut berjalan melalui dua jalur, yaitu jalur direct pass-through yang mempengaruhi inflasi langsung melalui efek harga impor dan indirect pass-through yang mempengaruhi inflasi melalui perubahan output gap akibat adanya perubahan neraca perdagangan. Studi transmisi moneter yang telah dilakukan di Bank Indonesia sebelumnya antara lain menyatakan bahwa jalur indirect pass-through hanya berjalan setelah periode krisis ${ }^{1}$, dan secara umum menyatakan bahwa jalur indirect pass-through tidak berjalan secara signifikan pada perekonomian Indonesia ${ }^{2}$. Studi ini akan mengkaji ulang jalur indirect pass-through, khususnya dalam melihat pengaruh perubahan nilai tukar riil terhadap net ekspor Indonesia dengan menggunakan pendekatan sisi permintaan dalam pemenuhan kondisi Marshall-Lerner.

Melalui jalur indirect pass-through, depresiasi nilai tukar akan menurunkan harga relatif ekspor dan meningkatkan daya saing produk ekspor tersebut sehingga permintaan luar negeri terhadap produk ekspor akan meningkat yang mengimplikasikan peningkatan volume ekspor. Sebaliknya harga produk impor menjadi lebih tinggi yang selanjutnya akan menekan permintaan produk impor sehingga volume impor akan menurun.

Peningkatan ekspor dan penurunan impor tersebut belum tentu akan meningkatkan nilai neraca perdagangan atau net ekspor. Neraca perdagangan hanya akan meningkat saat nilai tukar riil terdepresiasi bila persyaratan kondisi Marshall-Lerner yang terpenuhi, yaitu apabila jumlah elastisitas ekspor dan elastisitas impor terhadap nilai tukar riil lebih besar dari $1^{3}$. Depresiasi nilai tukar itu sendiri pada dasarnya akan mempengaruhi neraca

\footnotetext{
${ }^{1}$ Lihat Siswanto, et.al, 2002

${ }^{2}$ Lihat Astiyah, 2005

${ }^{3}$ Kondisi Marshall-Lerner itu sendiri berangkat dari sisi permintaan terhadap ekspor dan impor dengan asumsi dasar bahwa sisi penawaran perfectly elastic, sehingga berapapun permintaan yang terjadi akan selalu terpenuhi tanpa menyebabkan perubahan harga. Hal ini berarti harga ekspor maupun impor
} 
perdagangan melalui dua cara yaitu melalui perubahan volume dan perubahan nilai. Kondisi Marshall-Lerner menyatakan bahwa perubahan volume akan mendominasi perubahan nilai, sehingga meskipun nilai impor akan meningkat dan nilai ekspor akan menurun namun peningkatan volume ekspor dan penurunan volume impor akan mendominasi sehingga secara total neraca perdagangan akan membaik. Namun demikian, ada kecenderungan bahwa elastisitas akan lebih rendah dalam jangka pendek ${ }^{4}$ sehingga kondisi Marshall-Lerner kemungkinan hanya dapat terpenuhi pada jangka menengah dan jangka panjang. Fenomena ini dinamakan fenomena $J$-curve, dimana depresiasi nilai tukar menyebabkan neraca perdagangan pada awalnya akan memburuk sebelum akhirnya meningkat secara permanen. Hal ini disebabkan oleh pada jangka pendek volume ekspor dan volume impor tidak akan banyak berubah dan pengaruh harga akan lebih mendominasi, sehingga dalam jangka pendek neraca perdagangan akan memburuk. Terdapat beberapa penjelasan dibalik fenomena J-curve ini salah satunya bahwa perdagangan internasional biasanya berjalan berdasarkan kontrak yang sudah ditentukan sebelumnya sehingga perubahan volume ekspor dan impor tidak dapat berubah dengan serta merta mengikuti perubahan nilai tukar.

Di lain pihak, perubahan pada neraca perdagangan tidak hanya dipengaruhi oleh pergerakan nilai tukar riil saja, melainkan struktur dan industri ekspor itu sendiri juga memegang pengaruh yang dominan terhadap daya saing eskpor Indonesia. Besarnya import content, kuat atau lemahnya kontrol kualitas produk, ketepatan waktu pengiriman, kemampuan dalam penyesuaian kapasitas produksi dan hal lainnya, turut menentukan kondisi daya saing ekspor sehingga kebijakan nilai tukar saja tidak dapat dengan sendirinya meningkatkan kinerja ekspor Indonesia.

Studi ini bertujuan untuk mengevaluasi pemenuhan kondisi Marshall-Lerner pada perdagangan internasional Indonesia dengan beberapa negara mitra dagang utamanya secara bilateral, dan sekaligus mengetahui apakah terdapat fenomena $J$-curve pada masingmasing kasus. Pengkajian secara bilateral ini memiliki keunggulan dibandingkan dengan multilateral data secara agregat (Bahmani-Oskooee (2001)) di mana informasi yang lebih lengkap dapat lebih menjelaskan mixed results yang sering didapat dari estimasi agregat.

dianggap fixed dan tidak mempengaruhi permintaan, sehingga permintaan hanya berdasarkan atas harga relatif barang di luar dan dalam negeri yang diwakili oleh nilai tukar riil.

${ }^{4}$ Lihat misalnya Pilbeam (1998) dan Goldstein and Kahn (1985) 
Namun untuk memperoleh gambaran umum, estimasi agregat dari kedelepan mitra dagang juga tetap dilakukan.

Organisasi penulisan terdiri dari lima sesi. Sesi pertama ialah pendahuluan, sesi kedua menerangkan model dan metodologi yang digunakan, sesi ketiga menguraikan data yang digunakan, sesi keempat menyajikan hasil estimasi dan analisa, sesi terakhir kesimpulan. 


\section{MODEL $^{5}$}

Neraca perdagangan yang biasanya diukur berdasarkan deviasi antara ekspor dengan impor, pada model yang digunakan studi ini dinyatakan dalam rasio ekspor terhadap impor seperti pada Boyd et al (2001), Bahmani-Oskooee dan Kantipong (2001). Perhitungan ini lebih menguntungkan karena beberapa pertimbangan yaitu, menghasilkan kondisi Marshall-Lerner seutuhnya, rasio tersebut tidak sensitif terhadap satuan unit (Bahmani-Oskooee dan Alse (1994)), dan rasio tersebut dapat mewakili neraca perdagangan baik secara riil maupun secara nominal (Bahmani-Oskooee dan Brooks(1999)). Rasio ekspor nominal terhadap impor nominal, TB, diberikan oleh persamaan berikut,

$T B_{t}=\frac{P_{t} X_{t}}{P_{t}^{*} S_{t} M_{t}}$

di mana $X$ merupakan volume ekspor, $P$ harga domestik, $P^{*}$ harga luar negeri, $S$ nilai tukar nominal $^{6}$, dan $M$ volume impor. Dalam nilai nilai log, persamaannya akan menjadi,

$t b_{t}=x_{t}-m_{t}-\left(s_{t}-p_{t}+p_{t}^{*}\right)=x_{t}-m_{t}-r e r_{t}$

di mana rer merupakan nilai tukar riil.

Permintaan ekspor dan impor secara jangka panjang diberikan oleh persamaan berikut

$$
\begin{aligned}
& x_{t}=\alpha_{x}+\beta^{*} y_{t}^{*}+\eta_{x} r e r_{t} \\
& m_{t}=\alpha_{m}+\beta y_{t}-\eta_{m} r e r_{t}
\end{aligned}
$$

Sehingga neraca perdagangan jangka panjang ialah

$$
t b_{t}=\alpha_{x}-\alpha_{m}+\beta^{*} y_{t}^{*}-\beta y_{t}+\left(\eta_{x}+\eta_{m}-1\right) r e r_{t}
$$

Koefisien pada rer $_{t}$ memberikan kondisi Marshall-Lerner untuk suatu depresiasi (peningkatan rer) yang akan meningkatkan neraca perdagangan. Perumusan ini memperlihatkan sisi permintaan saja dengan asunmsi dasar bahwa elastisitas penawaran ekspor dan impor merupakan elastis sempurna sehingga perubahan volume permintaan tidak akan mempengaruhi harga.

\footnotetext{
${ }^{5}$ Kerangka teori dari kondisi Marshall-Lerner diuraikan dalam Apendiks 1

${ }^{6}$ Nilai tukar nominal dinyatakan sebagai unit mata uang domestik per satu unit mata uang luar negeri, sehingga peningkatan mencerminkan depresiasi.
} 
Persamaan (5) dapat dituliskan sebagai persamaan jangka panjang berikut

$t b_{t}=\alpha+\beta^{*} y_{t}^{*}-\beta y_{t}+\eta r e r_{t}$

di mana $\alpha=\alpha_{x}-\alpha_{m} ; \eta=\left(\eta_{x}+\eta_{m}-1\right)$ yang memperlihatkan kondisi Marshall-Lerner. Koefisien pada $y_{t}$ dapat memiliki tanda positif yaitu apabila kenaikan $y_{t}$ dihasilkan oleh adanya peningkatan produksi barang substitusi impor.

Persamaan (6) memperlihatkan hubungan ekuilibrium jangka panjang antara ke empat variable dalam neraca perdagangan bilateral. Jika asumsi dasar tidak terpenuhi, atau jika sisi permintaan tidak elastis sempurna sehingga terdapat perubahan harga ekspor atau impor yang dapat mempengaruhi sisi permintaan, kondisi Marshall-Lerner akan berbeda dari yang terlihat pada persamaan (6). Untuk mendapatkan pola penyesuaian dinamis (dynamic adjustment) dalam jangka pendek apabila terjadi shock pada system (khususnya shock pada variabel rer) dan untuk melihat apakah terdapat fenomena J-curve, dilakukan estimasi VECM untuk tiap hubungan bilateral tersebut. Dari (6) simpangan dari ekuilibrium jangka panjangnya ialah

$$
z_{t}=\alpha+\beta^{*} y_{t}^{*}-\beta y_{t}+\eta r e r_{t}-t b_{t}
$$

Meskipun jumlah cointegrating vector dari ke empat variable ini merupakan masalah empiris yang akan diteliti selanjutnya, untuk saat ini (7) dianggap sebagai satusatunya cointegrating vector. Bila $x_{t}=\left(t b_{t}, y_{t}, y^{*}, \text { rer }_{t}\right)^{\prime}$ merupakan vektor dari endogenous variabel maka penyesuaian dinamis dapat dimodelkan dengan vector autoregression (VAR) order ke- $p$ yang dapat dituliskan sebagai vector error correction model (VECM) pada hubungan kointegrasi $z_{t}$

$$
\Delta x_{t}=\mu+\alpha z_{t-1}+\sum_{i=1}^{p} \Gamma_{i} \Delta x_{t-1}+u_{t}
$$

di mana $\alpha$ ialah vector 4 x 1 . 


\section{DATA DAN METODOLOGI}

Secara empiris, estimasi dilakukan dengan menggunakan model Vector Error Correction (VECM). Model ini jamak dipergunakan untuk melihat keterkaitan dinamis antar variabel dan mengidentifikasi perilaku keseimbangan jangka pendek dan jangka panjang variabel-variabel tersebut.

Aplikasi model ini diawali dengan 3 langkah yang merupakan prosedur standar model autoregressive. Tahap pertama adalah pengujian unit root sebagai treatment awal yang harus dilakukan untuk melihat stasioneritas dari tiap variabel. Tahap kedua merupakan pemilihan lag order pada variable endogen berdasarkan Akaike Information Criteria (AIC) dan tahap ketiga merupakan pengujian keberadaan kointegrasi dengan menggunakan metode Johansen-Juselius (1990). Untuk mendapatkan pola penyesuaian dinamis pada VECM dilakukan perhitungan fungsi generalized impulse response (GIR) terhadap $b_{t}$ (lihat persamaan 7 pada bagian sebelumnya) untuk satu standar deviasi shock pada variabel rer $_{t}$. Metode ini memiliki kelebihan karena tidak sensitif terhadap urutan variable (ordering). ${ }^{7}$

Model tersebut diaplikasikan pada Indonesia dengan mitra dagang utamanya, yang mencakup 8 negara yakni Amerika Serikat, Singapura, Jepang, Korea Selatan, Cina, Taiwan, Inggris dan Jerman. Sample data kwartalan yang diestimasi meliputi periode 1993(1) sampai dengan 2004(4). Data ekspor dan impor yang digunakan ialah data non migas yang bersumber dari Statistik Ekonomi dan Keuangan (SEKI), sementara data lainnya bersumber dari CEIC dan IFS. Pemilihan ke delapan mitra dagang tersebut ialah berdasarkan rata-rata pangsa terbesar terhadap total ekspor impor Indonesia (Tabel 1).

Tabel 1.Rata-rata pangsa nilai ekspor dan impor periode 1993 - 2004

\footnotetext{
${ }^{7}$ Lihat Pesaran dan Shin, 1998.
} 


\begin{tabular}{|c|c|c|}
\hline \multirow{2}{*}{$\begin{array}{c}\text { Mitra } \\
\text { dagang }\end{array}$} & \multicolumn{2}{|c|}{ Rata $^{2}$ Pangsa } \\
\hline & Ekspor & Impor \\
\hline Jepang & $26.4 \%$ & $18.5 \%$ \\
\hline Amerika & $13.4 \%$ & $11.1 \%$ \\
\hline Singapura & $9.4 \%$ & $8.8 \%$ \\
\hline Korea Selatan & $6.5 \%$ & $5.8 \%$ \\
\hline China & $4.3 \%$ & $5.0 \%$ \\
\hline Taiwan & $3.7 \%$ & $4.0 \%$ \\
\hline Jerman & $2.7 \%$ & $6.1 \%$ \\
\hline Inggris & $2.3 \%$ & $2.2 \%$ \\
\hline Total & $69 \%$ & $61 \%$ \\
\hline
\end{tabular}

Data untuk variabel $y$ menggunakan data GDP Indonesia, sementara $y^{*}$ masingmasing menggunakan data GDP ke delapan negara mitra dagang yang dimasukkan dalam sample. Variabel $t b$ merupakan rasio dari data ekspor impor non migas dalam USD. Untuk pembentukkan varaibel rer digunakan data nilai tukar nominal yang dikalikan dengan rasio CPI masing-masing negara mitra dagang terhadap CPI Indonesia.

Sebelum estimasi dilakukan, deskripsi grafik yang disajikan di bawah ini, diharapkan mampu memberikan gambaran umum dan insight atas pola keseluruhan dari pergerakan data. Grafik 1 s/d 8 memperlihatkan pergerakan rasio ekspor impor dengan nilai tukar riil untuk masing-masing partner dagang.

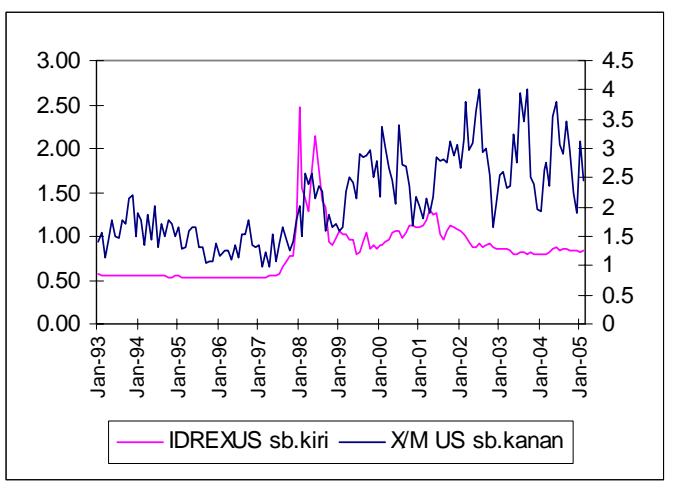

Garik 1

RER dan X/M dengan Amerika Serikat

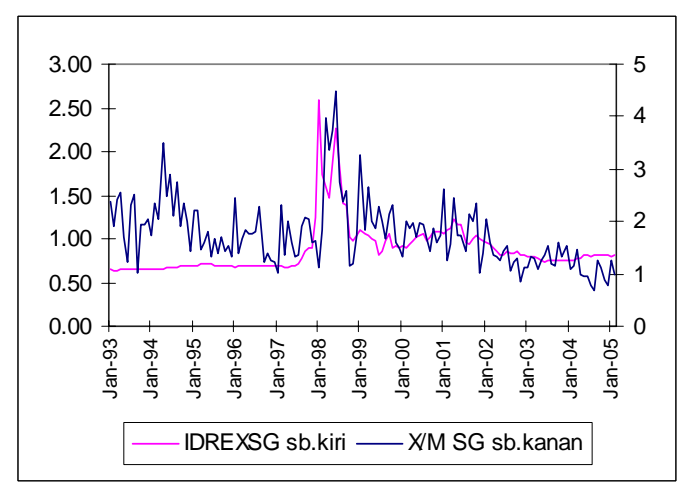

Grafik 2

RER dan X/M dengan Singapura 


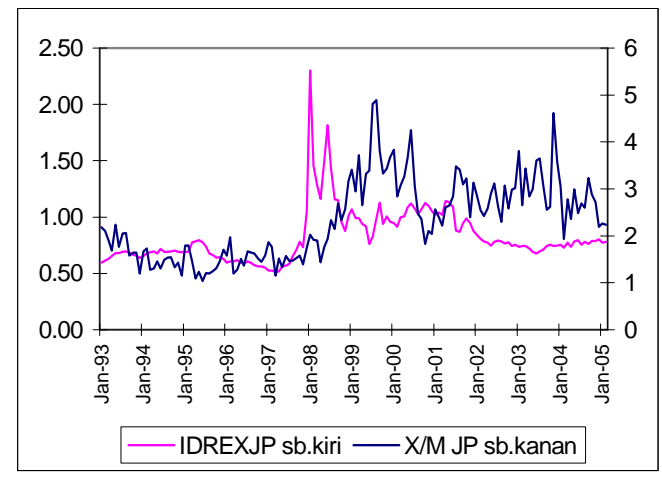

Grafik 3

\section{RER dan X/M dengan Jepang}

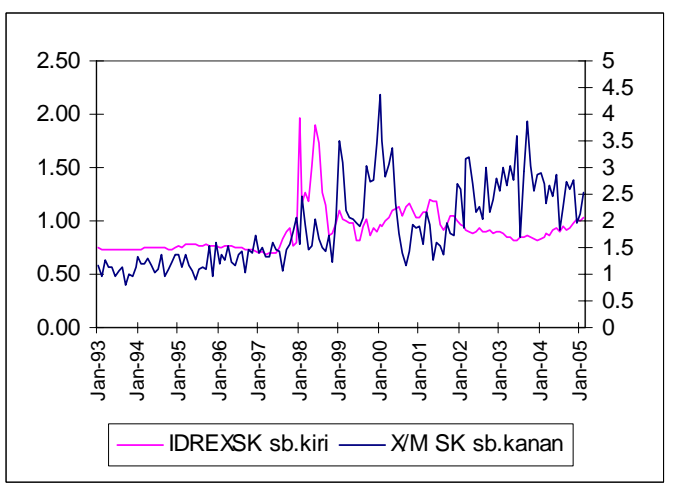

Grafik 4

RER dan X/M dengan Korea Selatan

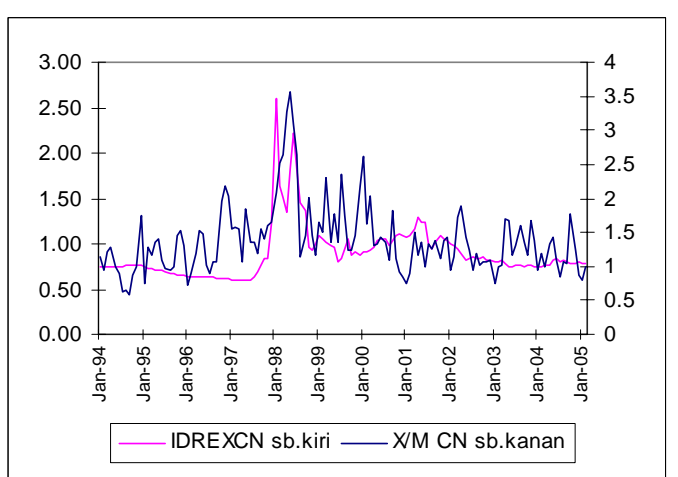

Grafik 5

RER dan X/M dengan Cina

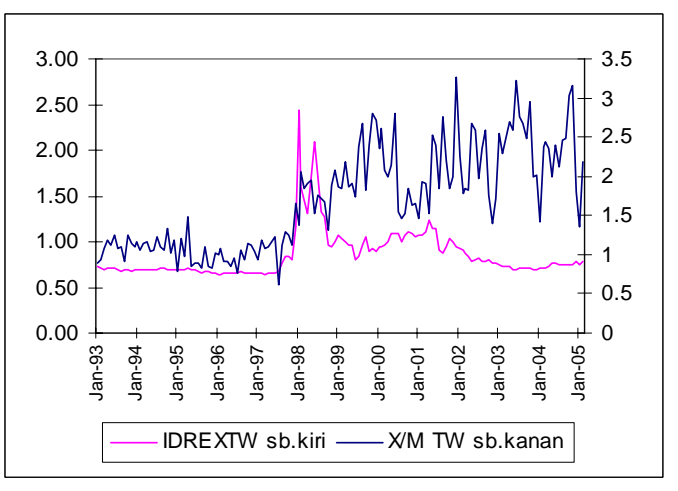

Grafik 6

RER dan X/M dengan Taiwan

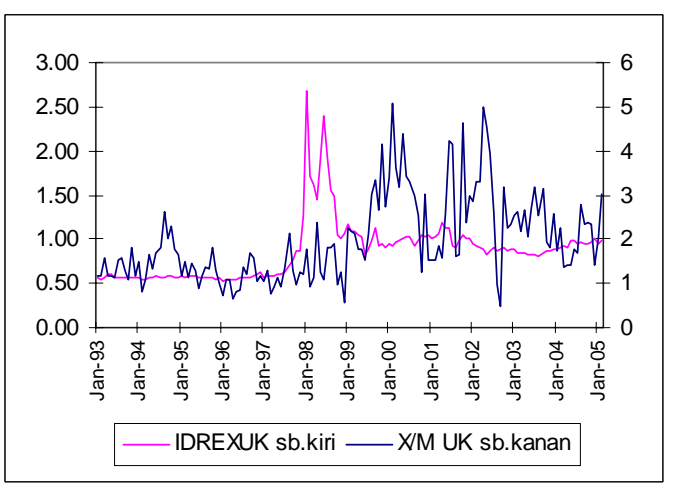

Grafik 7

\section{RER dan X/M dengan Inggris}

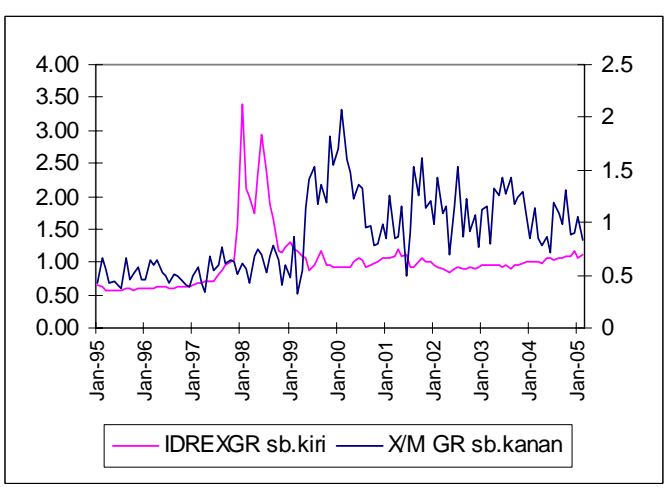

Grafik 8

RER dan X/M dengan Jerman 
Dari ke delapan grafik tersebut dapat dilihat bahwa secara umum rasio X/M memiliki trend jangka panjang yang searah dengan nilai tukar riil bilateral, kecuali untuk Singapura dan Cina. Pada kedua mitra dagang ini, trend nilai tukar riil yang memperlihatkan kecenderungan peningkatan sepanjang keseluruhan periode diikuti oleh trend penurunan pada rasio X/M. Hal ini mungkin akibat dari kenaikan nilai tukar riil yang justru diikuti oleh kenaikan impor dari kedua negara tersebut (Grafik A2 dan A3 pada Apendiks).

Beberapa grafik di atas juga memperlihatkan kemungkinan adanya break pada akhir 1997 yang ditandai oleh naiknya volatilitas RER yang diikuti oleh naiknya rasio X/M. Naiknya volatilitas RER ini terkait dengan pergantian rezim nilai tukar dari fixed menjadi managed floating pada Agustus 1997. Selanjutnya, pada mayoritas grafik di atas, rasio $\mathrm{X} / \mathrm{M}$ mengalami pergeseran ke atas yang cukup signifikan setelah periode break tersebut, kecuali untuk Singapura dan Cina dimana rasio X/M cenderung tetap mengikuti pola yang sama dengan periode sebelum adanya break yang mungkin terjadi.

Dari data agregat yang meliputi kedelapan mitra dagang tersebut, juga terlihat adanya hubungan positif antara rer dengan rasio X/M (Grafik 9) yang juga terutama terlihat setelah periode dimana terdapat kemungkinan break.

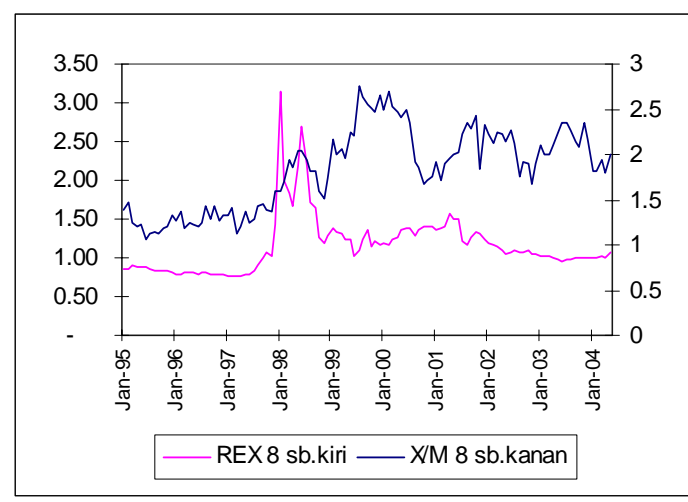

Grafik 9

RER dan X/M Agregat 8 Mitra Dagang

\section{Analisa Hasil Empiris}


Hasil uji unit root memperlihatkan bahwa seluruh variabel stasioner pada first difference, I(1) (Table 2). Selanjutnya untuk memilih panjang lag yang optimal dilakukan estimasi unrestricted VAR dengan keempat variable endogen secara bertahap. Pemilihan panjang lag optimal didasarkan pada kriteria AIC. Hasil estimasi unrestricted VAR memperlihatkan panjang lag yang berbeda, meskipun secara umum panjang lag yang optimal ialah 2. Akibatnya uji kointegrasi dan estimasi VECM dilakukan dengan menggunakan panjang lag yang berbeda antar mitra dagang (Tabel 3). Setelah VECM diestimasi, dilakukan pengujian pada residual yang meliputi autocorrelation LM test, normality test dan white heterocedasticity test. Hasil memperlihatkan bahwa residual pada tiap estimasi lulus ke tiga pengujian tersebut.

Tabel 2. ADF Test untuk Unit Root pada Level dan First Difference. (jumlah lag, * signifikan pada level 5\%)

\begin{tabular}{llll}
\hline Negara & $\mathrm{tb}_{\mathrm{t}}$ & $\mathrm{y}_{\mathrm{t}}{ }_{\mathrm{t}}\left(\mathrm{y}_{\mathrm{t}}\right)$ & $\mathrm{rer}_{\mathrm{t}}$ \\
\hline \hline Amerika & $-0.834(3)$ & $-0.979(2)$ & $-1.600(3)$ \\
& $-7.242\left(1,{ }^{*}\right)$ & $-2.943\left(1,{ }^{*}\right)$ & $-4.762\left(2,{ }^{*}\right)$ \\
Singapur & $-4.085\left(0,{ }^{*}\right)$ & $-2.166(2)$ & $-1.878(3)$ \\
& & $-6.137\left(1,{ }^{*}\right)$ & $-5.022\left(2,{ }^{*}\right)$ \\
Jepang & $-2.112(0)$ & $-0.856(4)$ & $-2.066(3)$ \\
& $-8.875\left(0,{ }^{*}\right)$ & $-3.594\left(3,{ }^{*}\right)$ & $-4.463\left(2,{ }^{*}\right)$ \\
Korea Selatar & $-2.836(0)$ & $-1.070(1)$ & $-2.727(3)$ \\
& $-6.982\left(1,{ }^{*}\right)$ & $-4.909\left(0,{ }^{*}\right)$ & $-4.466\left(2,{ }^{*}\right)$ \\
Cina & $-2.054(0)$ & $-2.630(0)$ & $-1.912(3)$ \\
& $-6.3300^{*}\left(2,{ }^{*}\right)$ & $-6.984\left(0,{ }^{*}\right)$ & $-4.640\left(2,{ }^{*}\right)$ \\
Taiwan & $-1.636(0)$ & $-2.051(4)$ & $-1.833(3)$ \\
& $-10.156\left(0,{ }^{*}\right)$ & $-3.039\left(3,{ }^{*}\right)$ & $-4.712\left(2,{ }^{*}\right)$ \\
Inggris & $-1.724(1)$ & $-1.933(0)$ & $-1.616(3)$ \\
& $-11.775\left(0,{ }^{*}\right)$ & $-4.871\left(0,{ }^{*}\right)$ & $-4.783\left(2,{ }^{*}\right)$ \\
Jerman & $-1.313(3)$ & $-1.764(1)$ & $-1.731(3)$ \\
& $-6.194\left(2,{ }^{*}\right)$ & $-8.601\left(0,{ }^{*}\right)$ & $-4.603\left(2,{ }^{*}\right)$ \\
Indonesia & \multicolumn{3}{c}{$-1.927(4)$} \\
& \multicolumn{3}{c}{$-2.924\left(3,{ }^{*}\right)$} \\
\hline
\end{tabular}

Dari analisis grafik sebelumnya, diduga telah terjadi break pada akhir periode 1997 sehingga terdapat kemungkinan perlu dimasukkannya variable dummy ke dalam estimasi. Variabel dummy tersebut memiliki nilai 0 pada saat sebelum kwartal ke empat tahun 1997 dan nilai 1 untuk lainnya. Namun demikian setelah dilakukan estimasi, pengikutsertaan variabel dummy ini memberikan hasil yang tidak konklusif. Hal ini dapat disebabkan oleh periode estimasi yang menjadi terlalu pendek jika dummy break dimasukkan. Sehingga, estimasi yang dilakukan selanjutnya tidak memasukkan variabel dummy tersebut. 
Dari hasil uji kointegrasi pada tiap sistem persamaan neraca perdagangan bilateral, secara umum terdapat satu cointegrating vector berdasarkan Johansen trace test pada level $1 \%$, kecuali untuk Inggris di mana terdapat satu cointegrating vector pada level $5 \%$. Selanjutnya dilakukan estimasi VECM untuk satu cointegrating vector yang dinormalisasi pada variabel $t b=-1$ untuk mendapatkan hubungan jangka panjang antar variabel.

Hasil estimasi elastisitas jangka panjang dari VECM (Tabel 3) memperlihatkan bahwa dari ke delapan mitra dagang, enam diantaranya memenuhi kondisi MarshallLerner di mana jumlah elastisitas ekspor dan impor lebih besar dari satu (koefisien pada rer pada persamaan (5) dan (6) yang lebih besar dari 0). Ke enam mitra dagang tersebut ialah Amerika, Jepang, Korea Selatan, Taiwan, Jerman dan Cina, namun untuk Cina estimasinya tidak signifikan. Temuan ini sejalan dengan studi oleh Onafowora (2003) untuk kasus perdagangan bilateral Indonesia dengan Amerika dan Jepang. Sementara itu, untuk neraca perdagangan dengan Singapura dan Inggris, kondisi Marshall-Lerner tidak terpenuhi. Hal ini terlihat dari koefisien pada rer yang memiliki tanda yang negatif. Namun demikian, jika estimasi dilakukan menggunakan data aggregat, maka kondisi MarshalLerner juga terpenuhi untuk neraca perdagangan Indonesia dengan kedelapan mitra dagang secara keseluruhan.

Tabel 3.

Hasil Estimasi VEC, jumlah cointegrating vector dgn trace statistik 1\% dan 5\% estimasi (SE) cointegrating vector dan adjustment coefficient [t-ratio], normalisasi $t b=-1$

\begin{tabular}{|c|c|c|c|c|c|c|c|c|c|}
\hline Negara & Tag & $1 \%$ & $5 \%$ & rer & $y$ & $y^{*}$ & $\alpha t b$ & $\alpha y$ & Qrer \\
\hline Amerika & 3 & 1 & 1 & $\begin{array}{l}-2.102 \\
(0.344)\end{array}$ & $\begin{array}{c}0.055 \\
(1.122)\end{array}$ & $\begin{array}{l}11.131 \\
(4.799)\end{array}$ & $\begin{array}{c}0.167 \\
{[1.749]}\end{array}$ & $\begin{array}{c}0.085 \\
{[7.043]}\end{array}$ & $\begin{array}{c}0.027 \\
{[0.402]}\end{array}$ \\
\hline Singapura & 2 & 1 & 1 & $\begin{array}{c}0.848 \\
(0.259)\end{array}$ & $\begin{array}{c}2.290 \\
(1.028)\end{array}$ & $\begin{array}{c}-4.078 \\
(1.340)\end{array}$ & $\begin{array}{c}0.269 \\
{[2.049]}\end{array}$ & $\begin{array}{c}-0.080 \\
{[-3.652]}\end{array}$ & $\begin{array}{c}-0.199 \\
{[-2.678]}\end{array}$ \\
\hline Jepang & 3 & 1 & 1 & $\begin{array}{l}-0.272 \\
(0.333)\end{array}$ & $\begin{array}{c}3.774 \\
(1.864)\end{array}$ & $\begin{array}{c}-12.352 \\
(5.113)\end{array}$ & $\begin{array}{c}0.248 \\
{[2.127]}\end{array}$ & $\begin{array}{c}-0.087 \\
{[-4.903]}\end{array}$ & $\begin{array}{c}0.098 \\
{[1.243]}\end{array}$ \\
\hline Korea Selatan & 2 & 1 & 2 & $\begin{array}{l}-4.929 \\
(0.896)\end{array}$ & $\begin{array}{l}-11.595 \\
(3.442)\end{array}$ & $\begin{array}{c}6.708 \\
(2.403)\end{array}$ & $\begin{array}{c}0.153 \\
{[2.322]}\end{array}$ & $\begin{array}{c}0.024 \\
{[2.311]}\end{array}$ & $\begin{array}{c}0.050 \\
{[1.799]}\end{array}$ \\
\hline China & 2 & 0 & 1 & $\begin{array}{l}-0.639 \\
(0.433)\end{array}$ & $\begin{array}{c}-0.663 \\
(1.009)\end{array}$ & $\begin{array}{c}-13.758 \\
(8.781)\end{array}$ & $\begin{array}{c}0.329 \\
{[3.408]}\end{array}$ & $\begin{array}{c}0.027 \\
{[1.527]}\end{array}$ & $\begin{array}{r}-0.107 \\
{[-1.680]}\end{array}$ \\
\hline Taiwan & 2 & 1 & 2 & $\begin{array}{l}-0.500 \\
(0.147)\end{array}$ & $\begin{array}{c}2.366 \\
(0.527)\end{array}$ & $\begin{array}{l}-2.496 \\
(0.949)\end{array}$ & $\begin{array}{c}0.188 \\
{[0.787]}\end{array}$ & $\begin{array}{c}-0.021 \\
{[-0.442]}\end{array}$ & $\begin{array}{c}0.432 \\
{[3.212]}\end{array}$ \\
\hline Inggris & 2 & 0 & 1 & $\begin{array}{c}2.388 \\
(0.523)\end{array}$ & $\begin{array}{c}7.831 \\
(2.444)\end{array}$ & $\begin{array}{c}-14.199 \\
(3.026)\end{array}$ & $\begin{array}{c}0.024 \\
{[0.308]}\end{array}$ & $\begin{array}{c}-0.034 \\
{[-3.435]}\end{array}$ & $\begin{array}{c}-0.034 \\
{[-0.840]}\end{array}$ \\
\hline Jerman & 3 & 1 & 3 & $\begin{array}{l}-3.295 \\
(0.588)\end{array}$ & $\begin{array}{l}-4.198 \\
(2.352)\end{array}$ & $\begin{array}{c}4.162 \\
(4.696)\end{array}$ & $\begin{array}{c}0.066 \\
{[1.625]}\end{array}$ & $\begin{array}{c}0.038 \\
{[6.059]}\end{array}$ & $\begin{array}{c}-0.012 \\
{[-0.438]}\end{array}$ \\
\hline Agregat 8 & 2 & 0 & 1 & $\begin{array}{l}-0.357 \\
(0.142)\end{array}$ & $\begin{array}{c}2.384 \\
(0.660)\end{array}$ & $\begin{array}{l}-4.606 \\
(0.689)\end{array}$ & $\begin{array}{c}0.136 \\
{[1.664]}\end{array}$ & $\begin{array}{c}-0.115 \\
{[-1.873]}\end{array}$ & $\begin{array}{c}0.172 \\
{[0.913]}\end{array}$ \\
\hline
\end{tabular}


Sementara itu untuk estimasi koefisien $y_{t}$ dan $y_{t}^{*}$, berdasarkan persamaan (3) dan (4) pada model, koefisien pada $y_{t}$ akan memiliki nilai negatif jika kenaikan pendapatan domestik menyebabkan kenaikan permintaan terhadap barang impor, sementara koefisien pada $y^{*}$ akan memiliki nilai positif jika kenaikan pendapatan luar negeri menyebabkan kenaikan permintaan terhadap barang ekspor dari domestik. Hasil estimasi pada Tabel 3 memperlihatkan bahwa ekspor dan impor Indonesia dengan Singapura, Jepang, Taiwan dan Inggris mengikuti persamaan (3) dan (4) tersebut. Di lain pihak, pada hasil estimasi neraca perdagangan dengan Jerman, koefisien pada $y_{t}$ memiliki nilai positif, hal ini dapat terjadi bila kenaikan $y_{t}$ disebabkan oleh kenaikan produksi barang substitusi impor. Sementara hasil estimasi koefisien $y_{t}{ }_{t}$ juga memiliki nilai positif, namun estimasi ini tidak signifikan. Untuk estimasi neraca perdagangan dengan Amerika, koefisien $y^{*}$ yang memiliki nilai negatif perlu dikaji lebih lanjut, karena secara umum tingkat upah di Indonesia lebih rendah jika dibandingkan dengan Amerika, sehingga kemungkinan Amerika memproduksi susbstitusi barang impor dari Indonesia cenderung kecil. Sementara koefisien $y_{t}$ yang memiliki nilai negatif memperlihatkan bahwa kenaikan pendapatan domestik akan menyebabkan kenaikan permintaan barang impor sehingga impor dari Amerika akan naik. Secara agregat, koefisien pada $y_{t}$ dan $y_{t}^{*}$ juga memenuhi persamaan (3) dan (4).

Untuk mengetahui pola penyesuaian dinamis neraca perdagangan yang terjadi bila terdapat shock pada nilai tukar riil, dilakukan perhitungan fungsi GIR yang ditampilkan pada Grafik 10 s/d 17. Terlihat bahwa fenomena $J$-curve terdapat pada neraca perdagangan Indonesia dengan Jepang, Korea Selatan, dan Jerman. Sementara untuk perdagangan Indonesia dengan Amerika dan Taiwan, depresiasi nilai tukar langsung dapat memperbaiki neraca perdagangan Indonesia. Untuk perdagangan Indonesia dengan Singapura dan Inggris, depresiasi nilai tukar justru pada awalnya akan memperbaiki neraca perdagangan, namun secara jangka panjang akan memburuk (inverted J-curve) sehingga dampak depresiasi nilai tukar secara jangka panjang terhadap neraca perdagangan ialah negatif.

Estimasi VECM untuk kondisi Marshall-Lerner dan pola penyesuaian dinamis dari perhitungan fungsi GIR pada tiap negara mitra dagang, secara umum sejalan dengan analisa grafik yang telah dilakukan sebelumnya. Jika dilihat lebih lanjut dari Grafik 1 dan 6, masing-masing untuk mitra dagang Amerika dan Taiwan, pada saat terjadi pelemahan nilai tukar riil yang secara signifikan terjadi pada kwartal pertama 1998, rasio X/M untuk kedua mitra dagang tersebut juga langsung meningkat. Kenaikan rasio X/M secara 
langsung ini kemingkinan lebih disebabkan oleh adanya penurunan impor dari kedua negara tersebut yang mulai berlangsung pada kwartal pertama 1998 (lihat Grafik A1 dan A6.pada Apendiks). Sejalan dengan persamaan (4), penurunan impor ini disebabkan oleh penurunan permintaan terhadap barang impor akibat adanya penurunan pendapatan riil Indonesia yang memang mulai terjadi sejak kwartal pertama 1998 sebagai efek dari krisis nilai tukar yang meluas menjadi krisis ekonomi. Namun, jika dilihat dari data komposisi impor ke Indonesia, impor bahan baku merupakan komponen terbesar yang sebagiannya juga akan digunakan sebagai bahan baku produksi dengan orientasi ekspor. Sehingga ekspor yang tetap mengalami peningkatan beberapa waktu setelah periode shock kemugkinan menggunakan stok bahan baku yang sudah ada. Pola GIR pada kedua negara juga memperlihatkan bahwa neraca perdagangan akan membaik sesaat namun setelah itu akan mengalami penurunan sebelum selanjutnya mengalami perbaikan secara jangka panjang. Penurunan sesaat ini dapat disebabkan oleh turunnya ekspor akibat turunnya bahan baku impor sebelum akhirnya mencapai keseimbangan baru. Berangkat dari kerangka teori kondisi Marshall-Lerner, ketiadaan pola J-curve pada neraca perdagangan dengan kedua mitra dagang ini dapat disebabkan oleh elastisitas impor jangka pendek yang cukup besar sehingga secara jangka pendek pun kondisi Marshall-Lerner sudah terpenuhi.

Pada kasus lainnya, untuk neraca perdagangan dengan Jepang, Korea Selatan dan Jerman, kondisi Marshall-Lerner juga terpenuhi. Namun demikian, elastisitas jangka pendek untuk ekspor dan impor masih lebih kecil jumlahnya dari 1 sehingga peningkatan neraca perdagangan akibat shock terhadap nilai tukar riil pada mulanya akan berdampak negatif pada neraca perdagangan sebelum secara jangka panjang memberikan dampak positif. Hasil empiris memperlihatkan bahwa neraca perdagangan baru akan terus membaik setelah 3 kwartal untuk Jepang dan Korea Selatan, dan 7 kwartal untuk Jerman. Hal ini juga terlihat dari pergerakan data pada Grafik 3, 4 dan 8 yang antara lain memperlihatkan bahwa setelah terjadi shock pada nilai tukar riil di kwartal pertama 1998, rasio X/M baru meningkat pada kwartal ketiga 1998 untuk Jepang, kwartal keempat untuk Korea Selatan dan kwartal kedua 1999 untuk Jerman. Memburuknya neraca perdagangan terhadap Jepang dan Korea Selatan tepat setelah shock nilai tukar riil pada kwartal pertama 1998 tersebut kemungkinan lebih disebabkan oleh tidak meningkatnya ekspor ke kedua negara tersebut meskipun impor sudah cenderung turun (Grafik A5 dan A7 pada Apendiks). Tidak membaiknya ekspor ke kedua negara ini lebih disebabkan oleh menurunnya permintaan terhadap barang ekspor domestik sebagai akibat dari menurunnya pendapatan riil di kedua 
mitra dagang tersebut, yang memang ikut terimbas oleh krisis ekonomi Asia pada tahun 1998. Penurunan harga relatif yang tercermin dari pelemahan nilai tukar riil ini baru direspon positif setelah kembali membaiknya pendapatan riil di kedua negara tersebut pada tahun 1999.

Di lain pihak, untuk neraca perdagangan dengan Jerman kinerjanya lebih ditentukan oleh penurunan impor dibandingkan dengan kenaikan ekspor (Grafik A8 pada Apendiks). Sehingga untuk perdagangan dengan Jerman, elastisitas imporlah yang diduga lebih berperan dalam pemenuhan kondisi Marshall-Lerner dibandingkan dengan elstisitas ekspor. Hal ini terlihat dari adanya penurunan impor yang cukup tajam, meskipun tidak langsung terjadi, sementara tidak ada peningkatan ekspor yang signifikan meskipun harga ekspor sudah menurun. Penurunan impor ini juga dapat disebabkan adanya barang susbtitusi impor dari negara lain atau dari produksi dalam negeri sendiri seperti halnya yang terlihat dari hasil estimasi dari koefisien $y_{t}$ yang memiliki nilai positif.

Sementara itu, untuk kedua mitra dagang yang tidak memenuhi kondisi MarshallLerner, yaitu Singapura dan Inggris, rendahnya elastisitas ekspor atau impor ini dapat disebabkan oleh hal yang berbeda antar negaranya. Untuk neraca perdagangan dengan Singapura, pelemahan nilai tukar riil yang justru diikuti oleh memburuknya neraca perdagangan secara jangka panjang dapat disebabkan oleh kecilnya elastisitas impor yang terlihat dari tetap meningkatnya permintaan terhadap barang impor meskipun harga barang impor sudah meningkat (Grafik A2). Hal ini memperlihatkan tingginya ketergantungan domestik terhadap barang impor dari Singapura. Pola ini juga sebenarnya terdapat pada perdagangan Indonesia dengan Cina. Situasi tersebut mungkin ditunjang oleh posisi Singapura sebagai entrepot sehingga impor dari Singapura dapat merupakan komoditas reekspor dari negara lain. Besar kemungkinan bahwa bahan baku impor yang dibutuhkan untuk produksi ekspor baik ke Singapura maupun ke negara lain masuk ke Indonesia melalui Singapura ${ }^{8}$. Hal ini mengakibatkan tingginya ketergantungan Indonesia terhadap impor dari Singapura.

Sementara itu, untuk neraca perdagangan dengan Inggris kecilnya elastisitas perdagangan kemungkinan lebih dipengaruhi oleh kecilnya elastisitas ekspor (Grafik A4

\footnotetext{
${ }^{8}$ Hal ini perlu didukung oleh data industri seperti banyaknya perusahaan multinational, sebagai produsen bahan baku impor yang dibutuhkan oleh industri ekspor Indonesia, yang membuka kantor cabang untuk South East Asia di Singapura.
} 
pada Apendiks). Hal ini terlihat dari kecilnya kenaikan ekspor ke Inggris meskipun harga relatif ekspor sudah lebih murah sementara di sisi lain pendapatan riil Inggris cenderung stabil. Kecilnya elastisitas ekspor ke Inggris anatar lain dapat dijelaskan bahwa jika dilihat dari komoditas utama yang di ekspor ke Inggris, secara umum barang yang diekspor merupakan barang konsumsi (lihat Tabel 1A pada Apendiks).

Jika dilihat secara agregat untuk kedelapan negara mitra dagang, depresiasi nilai tukar riil akan berdampak positif terhadap neraca perdagangan Indonesia meski dampaknya tidak terlalu besar (Grafik 18). Tidak terlihat fenomena J-curve pada penyesuaian dinamis neraca perdagangan, sehingga dalam jangka pendek elastisitas ekspor dan impor sudah cukup besar untuk memenuhi kondisi Marshall-Lerner.

Secara umum, dari hasil GIR pada Grafik 10 s/d 17 tersebut terlihat bahwa pengaruh depresiasi nilai tukar riil terhadap neraca perdagangan bilateral Indonesia tidaklah besar. Shock dari satu standar deviasi pada nilai tukar riil hanya menimbulkan efek sekitar $-0.02 \mathrm{~s} / \mathrm{d} 0.1$ pada neraca perdagangan bilateral dan 0.05 pada neraca perdagangan agregat. Hal ini memperlihatkan bahwa secara umum neraca perdagangan Indonesia jika hanya dilihat dari sisi permintaan terkait dengan kerangka teori kondisi Marshall-Lerner, tidak terlalu terpengaruh oleh perubahan nilai tukar riil.

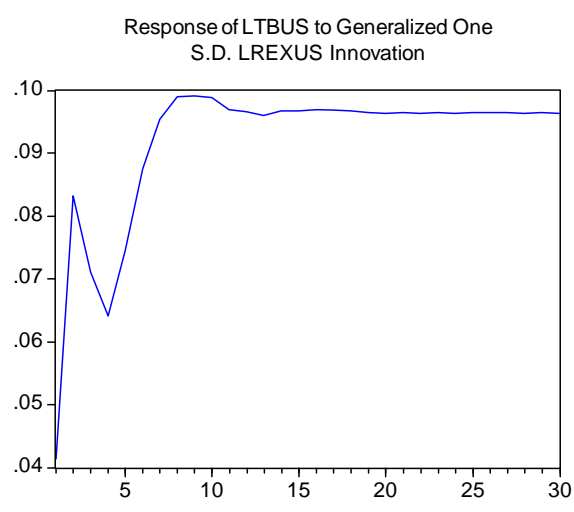

Grafik 10. GIR Amerika

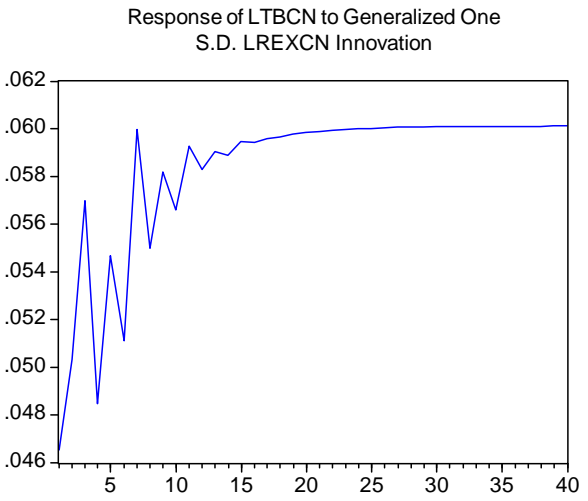

Grafik 12. GIR Cina 


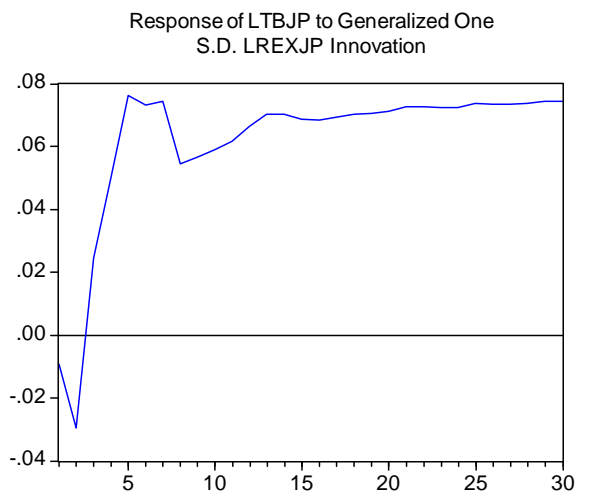

Grafik 14. GIR Jepang

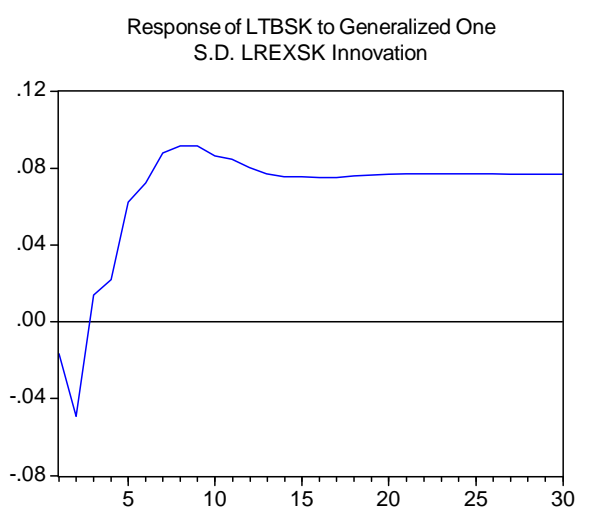

Grafik 11. GIR Korea Selatan

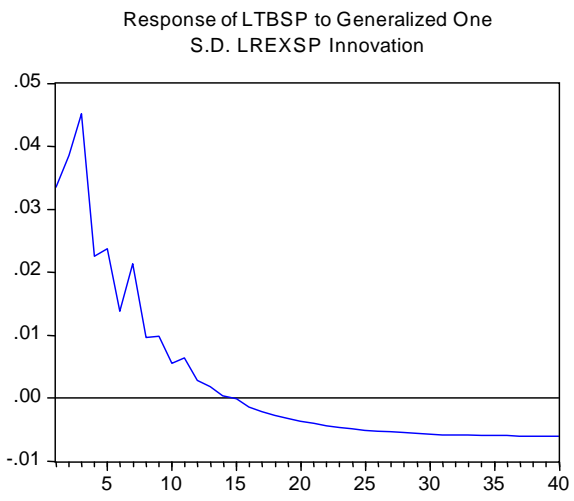

Grafik 13. GIR Singapura

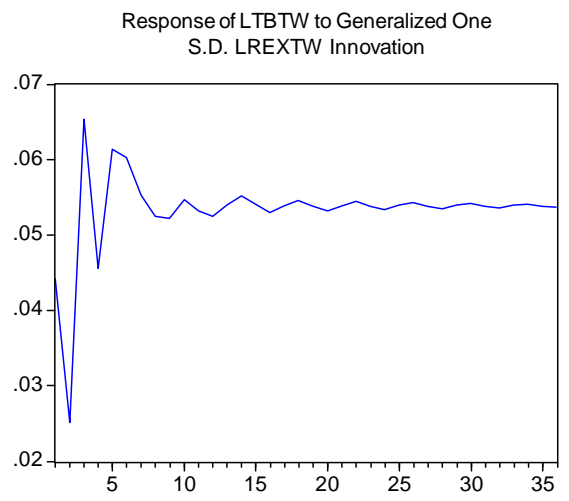

Grafik 15. GIR Taiwan

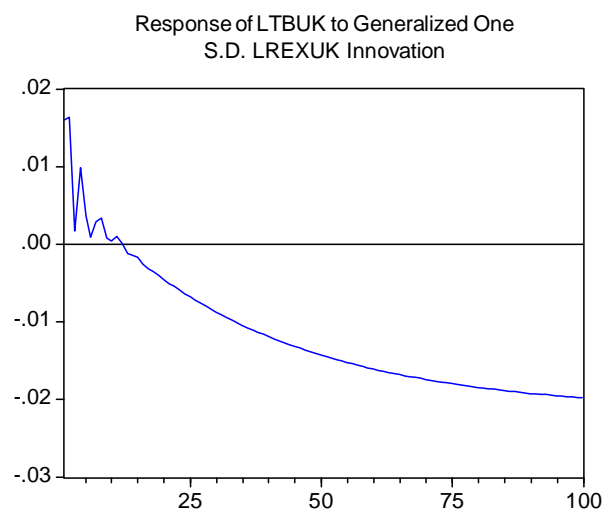

Grafik 16. GIR Inggris

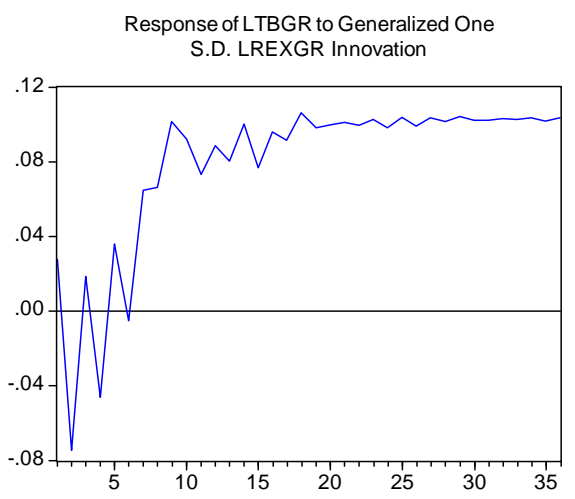

Grafik 17. GIR Jerman 


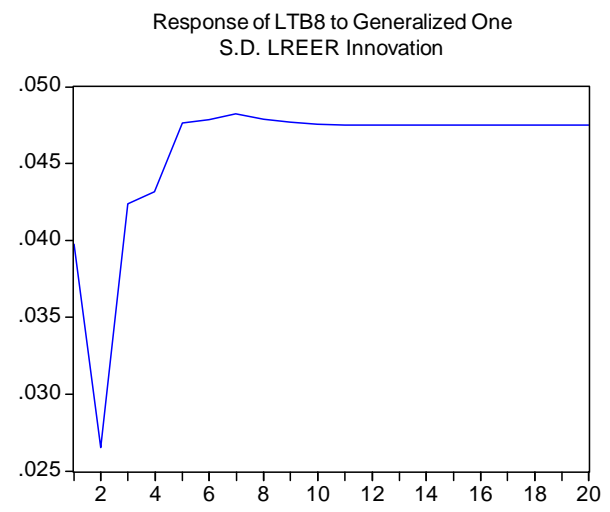

Grafik 18. GIR Agregat8

Hasil studi ini memperlihatkan bahwa efek jangka panjang dari perubahan nilai tukar riil terhadap neraca perdagangan Indonesia tidak lah besar. Namun faktor-faktor lain yang mempengaruhi sisi penawaran atau sisi produksi seperti kontrol kualitas, infleksibilitas kapasitas terpasang pada industri ekspor, efisiensi sistem produksi, besarnya import content dan lainnyalah, yang kemungkinan lebih mempengaruhi daya saing produk ekspor Indonesia, dan akhirnya dapat memperbaiki neraca perdagangan.

Untuk kebutuhan perumusan kebijakan nilai tukar, perlu dicermati bahwa besarnya direct-passthrough dari nilai tukar nominal kepada inflasi ${ }^{9}$ akan mempengaruhi besarnya depresiasi riil yang terjadi. Sebagai implikasinya, kebijakan depresiasi nilai tukar yang tidak disertai kebijakan yang mampu menekan efek direct-passthrough, tidak akan memiliki pengaruh besar terhadap kinerja neraca perdagangan.

Analisa perdagangan bilateral yang telah dilakukan ini sepenuhnya berdasarkan analisa dari sisi permintaan. Studi yang dapat menganalisa elastisitas per komoditas ekspor dan impor terhadap nilai tukar riil dari sisi penawaran akan dapat melengkapi penjelasan perilkau lalu lintas perdagangan bilateral Indonesia.

\footnotetext{
${ }^{9}$ Lihat misalnya hasil penelitian Astiyah (2005), reduced form model SOFIE dan model SSM.
} 


\section{KESIMPULAN}

1. Untuk periode 1993(1) - 2004(4), secara keseluruhan kondisi Marshall-Lerner terpenuhi pada hubungan perdagangan Indonesia (Tabel 1). Artinya depresiasi nilai tukar riil akan memperbaiki neraca perdagangan Indonesia. Di antara delapan Negara mitra dagang utama, kondisi Marshall-Lerner terpenuhi pada hubungan perdagangan Indonesia dengan Amerika, Jepang, Korea Selatan, Taiwan dan Jerman. Kondisi tersebut tidak terpenuhi pada hubungan perdagangan dengan Singapura karena rendahnya elastisitas impor akibat tingginya ketergantungan impor Indonesia dari Singapura, terutama dalam bentuk bahan baku untuk produksi. Kondisi tersebut juga tidak terpenuhi pada hubungan perdagangan dengan Inggris karena rendahnya elastisitas ekspor karena sebagian besar barang ekspor Indonesia ke negara tersebut dalam bentuk barang konsumsi. Perubahan daya saing ekspor Indonesia ke Inggris dari sisi rupiah relatif tidak mempengaruhi pendapatan riil negara tersebut karena dengan mudah disubstitusi ke barang yang sama dari negara pesaing Indonesia. Namun demikian, secara agregat, kondisi Marshall-Lerner untuk kedelapan negara mitra dagang tersebut tetap terpenuhi.

2. Secara agregat, fenomena $J$-curve tidak ditemukan dalam penyesuaian dinamis neraca perdagangan Indonesia dengan kedelapan mitra dagang utamanya. Artinya, depresiasi riil akan langsung memperbaiki neraca perdagangan Indonesia terhadap kedelapan mitra dagang tersebut. Namun, fenomena $J$-curve ditemukan pada neraca perdagangan Indonesia dengan Jepang, Korea Selatan dan Jerman, sehingga depresiasi riil pada awalnya akan berdampak negative terhadap neraca perdagangan Indonesia dengan kedua mitra dagang tersebut.

3. Sekalipun kondisi Marshall-Lerner terpenuhi, pengaruh depresiasi nilai tukar riil terhadap neraca perdagangan bilateral Indonesia relative kecil. Hasil estimasi elastisitas memperlihatkan bahwa dampak $1 \%$ depresiasi pada REER akan meningkatkan rasio ekspor terhadap impor untuk kedelapan mitra dagang tersebut sebesar $0.37 \%$. Kondisi ini menunjukkan bahwa terdapat faktor lain di luar nilai tukar yang lebih besar pengaruhnya terhadap kinerja net ekspor, khususnya dari sis penawaran, seperti misalnya kontrol kualitas produk, infleksibilitas kapasitas terpasang pada industri ekspor, efisiensi sistem produksi, besarnya import content.. 
4. Kebijakan nilai tukar yang tidak diikuti oleh kebijakan yang dapat menekan dampak direct-passthrough nilai tukar terhadap inflasi, secara jangka panjang tidak akan membawa dampak yang berarti terhadap kinerja neraca perdagangan Indonesia. Jika dampak direct-passthrough dapat ditekan, sehingga kebijakan nilai tukar secara efektif juga merupakan kebijakan nilai tukar riil, maka depresiasi nilai tukar dapat meningkatkan rasio ekspor terhadap impor Indonesia ke delapan mitra dagang utama (Tabel 4).

Tabel 4

\begin{tabular}{|c|c|c|c|c|}
\hline \multirow{2}{*}{$\begin{array}{c}\text { Mitra } \\
\text { dagang }\end{array}$} & \multicolumn{2}{|c|}{ Rata $^{2}$ Pangsa (1993-2004) } & \multirow{2}{*}{\begin{tabular}{|c|} 
Elastisitas \\
Net Ekspor $(\mathrm{X} / \mathrm{M})$ \\
\end{tabular}} & \multirow{2}{*}{$\begin{array}{c}\text { Kebijakan Depresias } \\
\text { Nilai Tukar Riil }\end{array}$} \\
\hline & Ekspor & Impor & & \\
\hline Jepang & $26.4 \%$ & $18.5 \%$ & 0.27 & Efektif \\
\hline Amerika & $13.4 \%$ & $11.1 \%$ & 2.10 & Efektif \\
\hline Singapura & $9.4 \%$ & $8.8 \%$ & -0.85 & Tidak Efektif \\
\hline Korea Selatan & $6.5 \%$ & $5.8 \%$ & 4.93 & Efektif \\
\hline China & $4.3 \%$ & $5.0 \%$ & - & 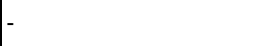 \\
\hline Taiwan & $3.7 \%$ & $4.0 \%$ & 0.5 & Efektif \\
\hline Jerman & $2.7 \%$ & $6.1 \%$ & 3.29 & Efektif \\
\hline Inggris & $2.3 \%$ & $2.2 \%$ & -2.38 & Tidak Efektif \\
\hline Total & $69 \%$ & $61 \%$ & 0.36 & Efektif \\
\hline
\end{tabular}




\section{DAFTAR PUSTAKA}

Astiyah, S (2005), "Pemetaan dan Peran Relatif Jalur Transmisi Kebijakan Moneter Paska Krisis”, Working Paper, Biro Riset Ekonomi, Bank Indonesia.

Bahmani-Oskooee, M. and T. Kantipong (2001),'Bilateral J-Curve Between Thailand and Her Trading Partners”, Journal of Economic Development, Vol. 26.

Bahmani-Oskooee, M. and J. Alse (1994),"Short-Run versus Long-Run Effects of Devaluation: Error Correction Modelling and Cointegration", Eastern Economic Journal, Vol. 20.

Bahmani-Oskooee, M. and T.J. Brooks (1999), "Bilateral J-Curve Between US and her Trading Partners,"Weltwirtschaftliches Archiv, Vol. 135.

Boyd, D., G. M. Caporale, R. Smithh (2001),'Real Exchange Effects on the Balance of Trade: Cointegration and the Marshall-Lerner Condition", International Journal of Finance and Economics, Vol.6: 187-200.

Dickey, D.A. and Fuller, W.A. (1981),'Likelihood Ratio Statistics for Autoregressive Time Series witha Unit Root", Econometrica, Vol. 49.

Johansen, S. (1988),"Statistical Analysis of Cointegration Vectors", Journal of Economic Dynamics and Control, Vol. 12.

Johansen, S. and Juselius, K (1990),"Maximum Likelihood Estimation and Inferences on Cointegration - with Application to Demand for Money", Oxford Bulletin of Economics and Statistics, Vol 52.

Model SOFIE, Direktorat Riset Ekonomi dan Kebijakan Moneter, Bank Indonesia.

Model SSM, Direktorat Riset Ekonomi dan Kebijakan Moneter, Bank Indonesia.

Onafowora, O. (2003),"Exchange rate and trade balance in east asia: is there a J-curve?" Economic Bulletin, Vol. 5.

Pesaran, M. H. and Shin, Y. (1998),"Generelized Impulse Response Analysis in Linear Multivariate Model”, Economic Letters, Vol. 58.

Warjiyo, P. (2004), "Ekonomi Keuagan Internasional: Teori, Model Empiris dan Kebijakan", Bahan Kuliah Pascasarjana Universitas Indonesia Program Studi Ilmu Ekonomi. 


\section{APENDIKS 1}

\section{Kerangka Teori Kondisi Marshall-Lerner; Pendekatan Elastisitas terhadap Neraca Perdagangan}

Analisis ini dipelopori oleh Alferd Marshall, Abba Lerner dan kemudian dilengkapi oleh Joan Robinson (1937) dan Firtz Machlup (1955).

Model ini hanya fokus pada kondisi sisi permintaan dan berangkat dari asumsi dasar bahwa elastisitas penawaran barang ekspor domestik dan barang impor merupakan elastis sempurna, sehingga perubahan pada volume permintaan tidak akan mempengaruhi harga. Implikasi dari asumsi ini adalah harga domestik dan harga luar negeri tetap (fixed), sehingga semua permintaan dapat diserap tanpa menimbulkan kenaikan atau penurunan harga.

Neraca perdagangan (TB) jika ditampilkan dalam mata uang domestik ialah:

$T B=P X_{v}-S P^{*} M_{v}$

di mana $P$ merupakan tingkat harga domestik, $X_{v}$ merupakan volume ekspor, $S$ merupakan nilai tukar nominal (harga nilai tukar domestik per satu unit nilai tukar luar negeri/partner dagang), $P^{*}$ merupakan tingkat harga luar negeri dan $M_{v}$ merupakan volume impor. Untuk penyederhanaan tingkat harga domestik dan luar negeri dimisalkan sama dengan 1, sehingga nilai ekspor $\left(P X_{v}\right)$ diberikan oleh $X$, dan nilai impor $\left(P^{*} M_{v}\right)$ diberikan oleh $M$.

$T B=X-S M$

Dalam bentuk diferensial (2) menjadi

$d T B=d X-S d M-M d S$

Dengan membagi (3) dengan perubahan nilai tukar, dS, didapatkan

$\frac{d T B}{d S}=\frac{d X}{d S}-S \frac{d M}{d S}-M \frac{d S}{d S}$

Sementara itu didefinisikan terlebih dahulu bahwa elastisitas harga pada permintaan ekspor $\eta_{\mathrm{x}}$, ialah persentase perubahan ekspor terhadap persentase perubahan nilai tukar:

$\eta_{x}=\frac{d X / X}{d S / S}$

sehingga 
$d X=\eta_{x} \frac{d S}{S} X$

dan elastisitas harga pada permintaan impor $\eta_{\mathrm{m}}$ didefiniskan sebagai persentase perubahan impor terhadap persentase perubahan nilai tukar:

$\eta_{m}=-\frac{d M / M}{d S / S}$

sehingga

$d M=-\eta_{m} \frac{d S}{S} M$

Dengan mensubstitusikan (5) dan (6) ke (4) didapat:

$\frac{d T B}{d S}=\frac{\eta_{x} X}{S}+\left(\eta_{m} M\right)-M$

dibagi $M$ menjadi

$\frac{d T B}{d S} \frac{1}{M}=\frac{\eta_{x} X}{S M}+\eta_{m}-1$

Dengan mengasumsikan neraca perdagangan yang seimbang $\mathrm{X} / \mathrm{SM}=1$, dan dengan merubah susunan (7) menjadi

$\frac{d T B}{d S}=M\left(\eta_{x}+\eta_{m}-1\right)$

Persamaan (8) dikenal sebagai kondisi Marshall-Lerner yang menyatakan bahwa berangkat dari kondisi keseimbangan pada neraca perdagangan, depresiasi nilai tukar dapat memperbaiki neraca perdagangan, $d T B / d S>0$, hanya jika jumlah elastisitas ekspor dan elastisitas impor lebih besar dari satu.

Penjelasan dari kondisi tersebut ialah sebagai berikut:

Perubahan nilai tukar akan menyebabkan dua perubahan, yaitu perubahan nilai dan perubahan volume. Pada saat terjadi depresiasi nilai tukar, maka terjadi dua perubahan tersebut:

1. Perubahan nilai: ekspor menjadi lebih murah bila diukur dari mata uang negara mitra dagang. Perubahan nilai ini akan menurunkan nilai ekspor dalam mata uang mitra dagang (misal dalam dollar).

2. Perubahan volume: volume permintaan terhadap barang ekspor domestik menjadi lebih tinggi karena ekspor menjadi lebih murah, sebaliknya karena impor menjadi lebih mahal permintaan terhadap barang impor menurun. Jadi perubahan volume akan berpengaruh positif terhadap neraca perdagangan. 
Kondisi Marshall-Lerner menyatakan bahwa perubahan volume akan mendominasi perubahan nilai, sehingga meskipun nilai impor akan meningkat dan nilai ekspor akan menurun namun peningkatan volume ekspor dan penurunan volume impor akan mendominasi sehingga secara total neraca perdagangan akan membaik. 

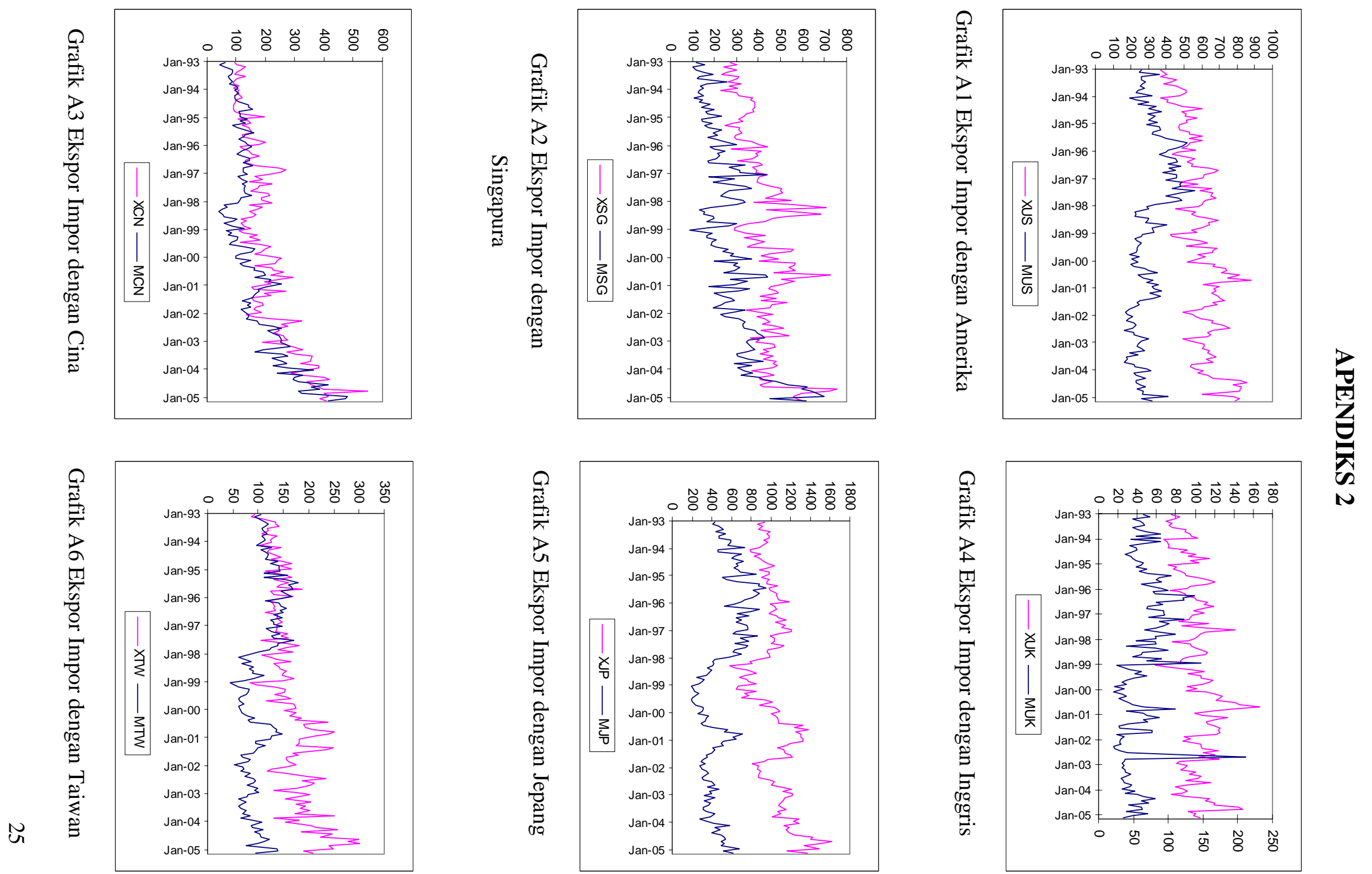

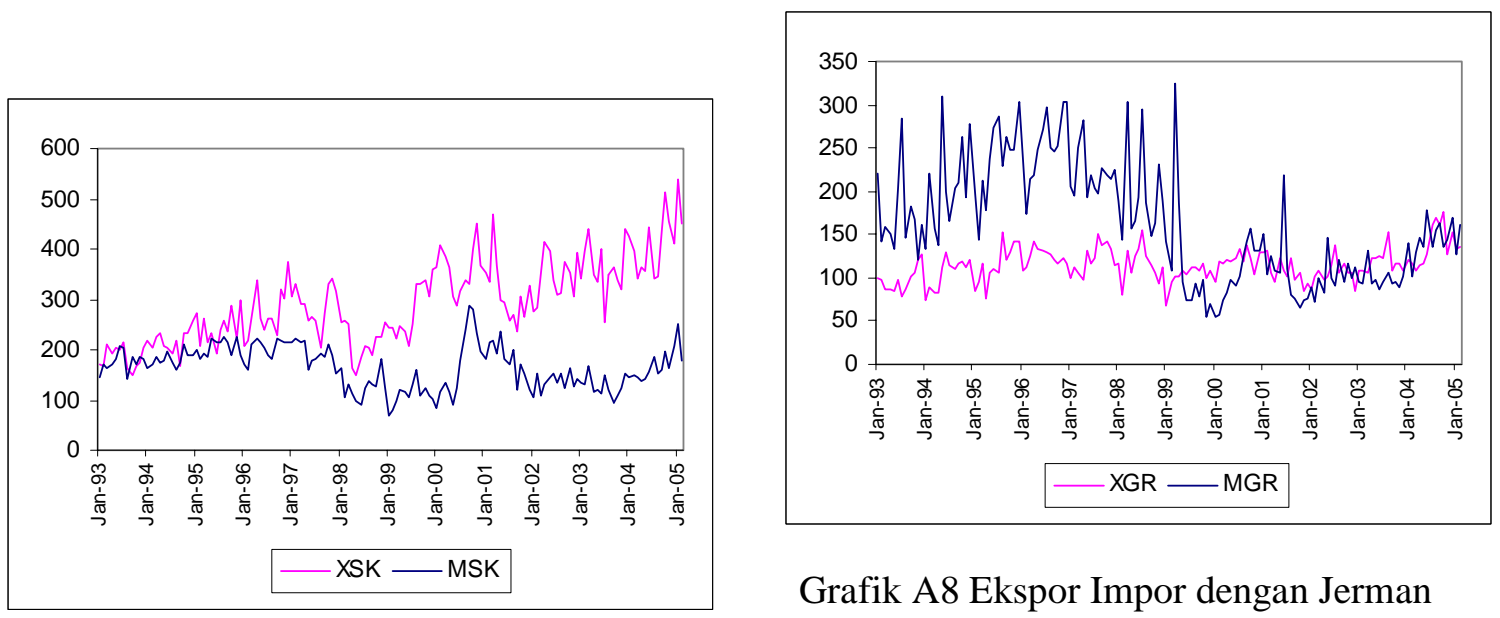

\section{Grafik A8 Ekspor Impor dengan Jerman}

\section{Grafik A7 Ekspor Impor dengan Korea}

\section{Selatan}

\section{Tabel A1}

\begin{tabular}{|c|c|c|c|}
\hline Negara & Kelompok Komoditas Ekspor & $\begin{array}{c}\text { Import } \\
\text { content } \\
(\%)\end{array}$ & Share (\%) \\
\hline \multirow[t]{3}{*}{ Amerika } & Pakaian jadi & 14 & 26 \\
\hline & Karet perkebunan & 4 & 10 \\
\hline & Perlengkapan elektronik & 18 & 10 \\
\hline \multirow[t]{3}{*}{ Jepang } & Mineral & 2 & 33 \\
\hline & Industri kayu gergajian $\&$ awetan & 5 & 8 \\
\hline & Budidaya \& penangkapan udang & 0 & 5 \\
\hline \multirow[t]{3}{*}{ Singapura } & Mesin dan pesawat mekanik & 48 & 41 \\
\hline & Mineral & 2 & 9 \\
\hline & P erlengkapan listrik lainnya & 19 & 6 \\
\hline Korea & Mineral & 2 & 31 \\
\hline \multirow[t]{2}{*}{ Selatan } & Industri kertas & 30 & 10 \\
\hline & Barang jadi tekstil & 48 & 7 \\
\hline \multirow[t]{3}{*}{ Cina } & Industri minyak nabati dan hewani & 3 & 17 \\
\hline & Industri kertas & 30 & 11 \\
\hline & Industri kimia dasar & 23 & 10 \\
\hline \multirow[t]{3}{*}{ Taiwan } & Mineral & 2 & 40 \\
\hline & Industri kayu gergajian \& awetan & 5 & 8 \\
\hline & Industri kertas & 30 & 7 \\
\hline \multirow[t]{4}{*}{ Inggris } & Pakaian jadi & 14 & 14 \\
\hline & Alas kaki & 6 & 9 \\
\hline & Industri kayu gergajian $\&$ awetan & 5 & 8 \\
\hline & Mesin dan pesawat mekanik & 54 & 5 \\
\hline \multirow[t]{4}{*}{ Jerman } & Pakaian jadi & 14 & 20 \\
\hline & Industri minyak nabati dan hewani & 3 & 8 \\
\hline & Alat listrik untuk rumah tangga & 18 & 5 \\
\hline & Karet perkebunan & 4 & 5 \\
\hline
\end{tabular}

Sumber:

- Data PDIE 2004 diolah

- Perhitungan Import content oleh Tri Yanuarti 